\title{
Association between C-reactive protein and risk of schizophrenia: An updated meta-analysis
}

\author{
Zhichao Wang ${ }^{1}$, Ping $\mathrm{Li}^{2}$, Dianyuan $\mathrm{Chi}^{1}$, Tong $\mathrm{Wu}^{2}$, Zubing $\mathrm{Mej}^{3}$ and Guangcheng \\ $\mathrm{Cui}^{2}$ \\ ${ }^{1}$ Academic Research Department, Qiqihar Medical University, Qiqihar, Heilongjiang Province, China \\ ${ }^{2}$ Department of Psychiatry, Qiqihar Medical University, Qiqihar, Heilongjiang Province, China \\ ${ }^{3}$ Department of Anorectal Surgery, Shuguang Hospital, Shanghai University of Traditional Chinese Medicine, Shanghai, China \\ Correspondence to: Guangcheng Cui, email: cui_guangcheng@163.com, cuigchengdr@sina.com \\ Zubing Mei, email: herrmayor@126.com
}

Keywords: C-reactive protein, schizophrenia, risk, meta-analysis

Received: March 24, $2017 \quad$ Accepted: May 06, $2017 \quad$ Published: May 18, 2017

Copyright: Wang et al. This is an open-access article distributed under the terms of the Creative Commons Attribution License 3.0 (CC BY 3.0), which permits unrestricted use, distribution, and reproduction in any medium, provided the original author and source are credited.

\section{ABSTRACT}

C-reactive protein (CRP) has been indicated to be associated with the pathogenesis of schizophrenia (SZ) and other psychiatric disorders. The aim of this study is to investigate whether peripheral blood CRP levels are associated with the risk of SZ. We searched literature from databases of Pubmed, Embase and the Cochrane Library from inception to November 1, 2016 for studies that reported serum or plasma CRP levels in patients with SZ and non-SZ controls. At least two reviewers decided on eligibility and extracted data from included studies. Random effects meta-analyses were performed using standardized mean difference (SMD) as the effect estimate of the differences in CRP levels between subjects with SZ and healthy controls. We identified 18 studies representing 1963 patients with SZ and 3683 non-SZ controls. Compared with non-schizophrenics, blood CRP levels were moderately increased in people with SZ (SMD $0.53,95 \%$ CI 0.30 to 0.76 ) irrespective of study region, sample size of included studies, patient mean age, age of SZ onset and patient body mass index. Publication bias was not detected through Egger's linear regression test $(P=0.292)$. We noticed that patients in Asia or Africa ( $n=6$, SMD 0.73, 95\% CI 0.26 to 1.21) and whose age less than 30 years ( $n=5$, SMD $0.76,95 \%$ CI 0.07 to 1.58 ) had substantially higher CRP levels. Our study provides evidence that higher CRP levels are associated with increased risk of SZ, especially for young adult patients less than $\mathbf{3 0}$ years. Further large-scale studies are strongly warranted to further confirm this association.

\section{INTRODUCTION}

Immune system dysfunctions and inflammatory processes have been implicated in the pathogenesis of schizophrenia (SZ) [1-5]. A vast observational studies, mainly case-control studies provide increasing evidence that patients with SZ have elevated levels of some inflammatory biomarkers, such as cytokines in plasma or serum $[1,4]$. Furthermore, evidence from epidemiologic studies implied that some autoimmune diseases contributed to the development of SZ [6, 7]. As an acutephase protein, $\mathrm{C}$-reactive protein (CRP) is produced by some inflammatory stimula and is mainly induced by some pro-inflammatory cytokines [8]. Increased CRP levels have been reported in numerous observational studies in psychosis including SZ and in bipolar disorder [9]. Metcalf et al. reported that individuals with high $(>3 \mathrm{mg} / \mathrm{L})$ compared with low $(<1 \mathrm{mg} / \mathrm{L}) \mathrm{CRP}$ levels at baseline were more likely to develop SZ (adjusted odd ratio 4.25, 95\% CI, 1.30 to 13.93) [55]. Zhang et al. found that high sensitivity CRP/ interleukin-10 was a potential peripheral biomarker of SZ [56].

It has also been indicated that the increase in serum or plasma CRP levels contributes the risk of a first episode of SZ [9]. Inoshita et al. conducted a mendelian randomisation study and found a causal relationship 
between increased CRP levels and the development of SZ [10]. However, several other studies reported no association between CRP levels and risk of SZ [11-13]. A meta-analysis by Fernandes et al published in 2015 of CRP levels in patients with SZ found that CRP was increased in SZ but was not altered by antipsychotics [14]. However, owing to the mixed studies combined for both case-control and cross-sectional studies in meta-analysis, we would like to update the evidence for only case-control studies published in English peer review journals.

\section{RESULTS}

\section{Description of the included studies}

The literature search yielded 927 citations. After excluding the duplicate, 39 appeared relevant and were retrieved for full-text review afer reading the titles or abstracts (Figure 1). In summary, 18 studies recruiting 1963 patients with SZ and 3683 non-SZ controls were enrolled in this meta-analysis [10-13, 15-28]. Detailed characteristics of individual studies are presented in Table 1. The sample size of included studies ranged from 60 to 1783 participants. Eleven studies were conducted in European countries, six in Asian or African countries and one in USA. Three studies recruted participants from inpatient unit, while another three from outpatient unit, eight from both units and four from population-based samples. Seven studies enrolled patients with age of SZ onset less than 30 years and two more than 30 years. Five studies investigated participants with body mass index less than $25 \mathrm{~kg} / \mathrm{m}^{2}$ and 11 studies with the range from 25 to $30 \mathrm{~kg} / \mathrm{m}^{2}$. Most of the studies (17/18) applied highsensitivity CRP assay except for one [13]. Twelve of the 18 included studies were of high quality and the remaining six studies were assessed as medium quality.

\section{Meta-analysis of Association between CRP and Risk of Schizophrenia}

Meta-analysis based on 18 studies, showed that compared with non-schizophrenics, CRP levels were

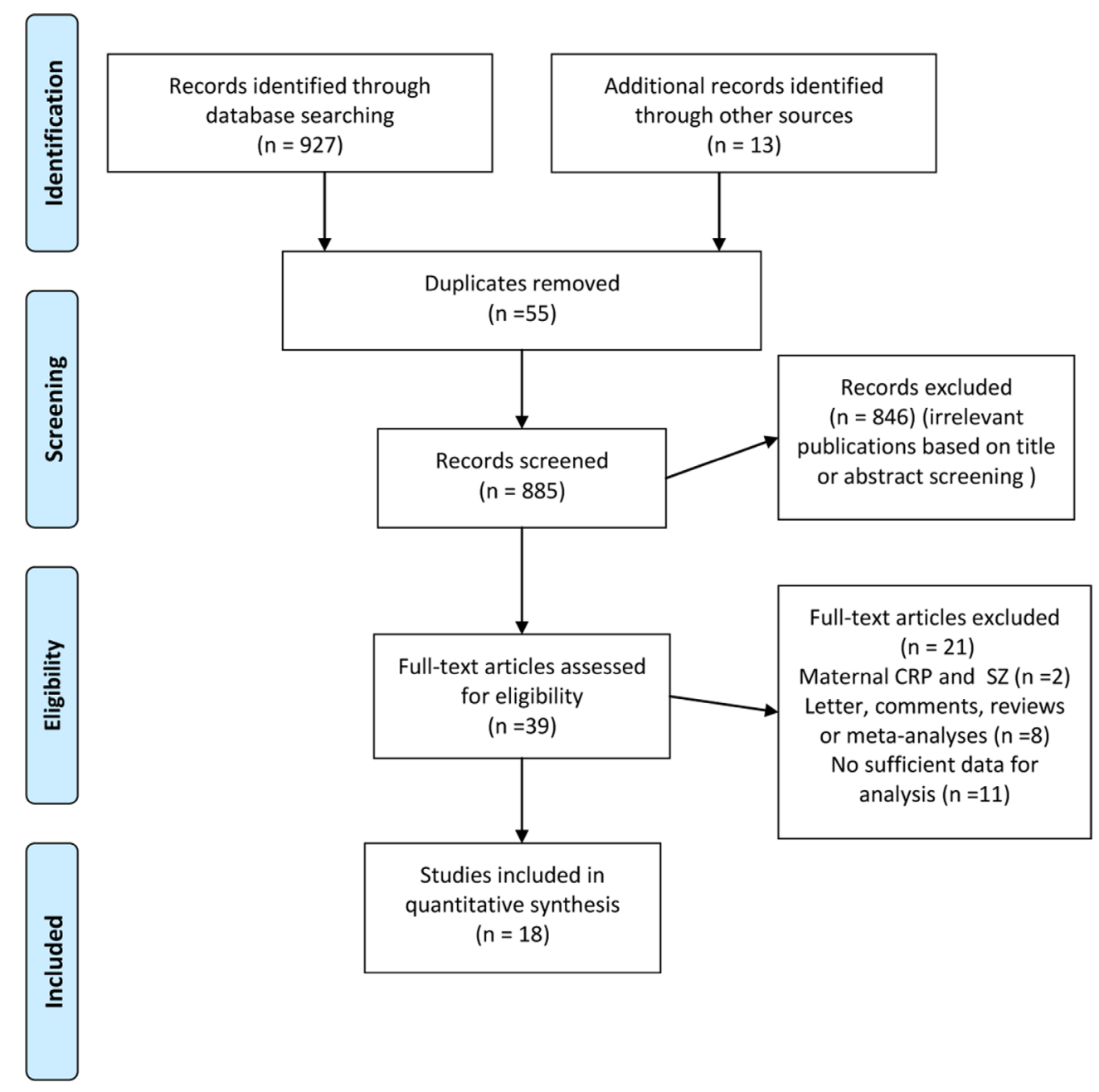

Figure 1: Preferred reporting items for systematic reviews and meta-analyses flow diagram depicting overview of study-selection process for studies reporting on C-reactive protein and risk of schizophrenia. 
Table 1: Characteristics of the included studies in the meta-analysis investigating the association between $\mathrm{C}$-reactive protein and risk of schizophrenia

\begin{tabular}{|c|c|c|c|c|c|c|c|c|c|c|c|c|c|}
\hline Study & Year & Country & Subjects & $\begin{array}{l}\text { Sex Male/ } \\
\text { Female }\end{array}$ & Setting & $\begin{array}{c}\text { Meanage } \\
\text { (years) }\end{array}$ & $\begin{array}{c}\text { Meanage } \\
\text { of onset } \\
\text { (years) }\end{array}$ & $\begin{array}{c}\text { Mean } \\
\text { BMI }\end{array}$ & $\begin{array}{l}\text { Adjusted } \\
\text { variables for } \\
\text { controls }\end{array}$ & $\begin{array}{c}\text { Current } \\
\text { Smokers } \\
(\%)\end{array}$ & CRP assay type & Comorbidities & $\begin{array}{l}\text { Psychiatric } \\
\text { drugs }\end{array}$ \\
\hline $\begin{array}{l}\text { Sarandol } \\
\text { et al., }\end{array}$ & 2007 & Turkey & $\begin{array}{l}\text { Chronic } \\
\text { SZ } \\
\text { Control }\end{array}$ & $\begin{array}{l}18 / 22 \\
17 / 18\end{array}$ & $\begin{array}{l}\text { Inpatient and } \\
\text { outpatient } \\
\text { unit }\end{array}$ & 34.933 .5 & NA & 23.724 .6 & $\begin{array}{l}\text { Age, BMI, } \\
\text { smoking } \\
\text { status }\end{array}$ & NA & $\begin{array}{l}\text { Plasma, high sensitive } \\
\text { immunonephrelometry } \\
\text { assay }\end{array}$ & $\begin{array}{l}\text { Exclusions: } \\
\text { DM and use of } \\
\text { anti-inflammatory } \\
\text { or, HAS, CVD, } \\
\text { infections } \\
\text { immunossupressants }\end{array}$ & $\begin{array}{l}\text { Drug-naïve } \\
\text { or free }\end{array}$ \\
\hline $\begin{array}{l}\text { Carrizo } \\
\text { et al. }\end{array}$ & 2008 & Venezuela & \begin{tabular}{|l} 
Chronic \\
SZ \\
Control
\end{tabular} & $48 / 40$ & $\begin{array}{l}\text { Inpatient and } \\
\text { outpatient } \\
\text { unit }\end{array}$ & 43.254 .79 & NA & 27.528 .6 & No & NA & $\begin{array}{l}\text { Serum, high sensitive } \\
\text { enzime immunoassay }\end{array}$ & \begin{tabular}{|l|} 
Exclusions: DM \\
, HAS, CVD, \\
infections and use of \\
anti-inflammatory or \\
immunossupressants
\end{tabular} & \begin{tabular}{|l} 
Typical and \\
Atypical \\
antipsychotics \\
\end{tabular} \\
\hline $\begin{array}{l}\text { Akanji } \\
\text { et al., } 2009\end{array}$ & 2009 & Kuwait & \begin{tabular}{|l|} 
Chronic \\
SZ \\
Control
\end{tabular} & $141 / 62$ & $\begin{array}{l}\text { Inpatient } \\
\text { unit }\end{array}$ & \begin{tabular}{|l|}
$141 / 62$ \\
$165 / 0$
\end{tabular} & NA & $\begin{array}{l}39.80 \\
39.50\end{array}$ & $\begin{array}{l}\text { Age, race, } \\
\text { socioeconomic } \\
\text { status }\end{array}$ & NA & $\begin{array}{l}\text { Serum, high sensitive } \\
\text { Chemiliminescent } \\
\text { immunometric assay }\end{array}$ & \begin{tabular}{|l|} 
Exclusions: DM, \\
HAS, CVD, \\
infections \\
and use of anti- \\
inflammatory or \\
immunossupressants
\end{tabular} & \begin{tabular}{|l|} 
Typical \\
antipsychotics
\end{tabular} \\
\hline $\begin{array}{l}\text { Fernandes- } \\
\text { Egea et al., } \\
2009\end{array}$ & 2009 & Spain & \begin{tabular}{|l|} 
SZ in \\
FEP \\
Control
\end{tabular} & $\begin{array}{l}35 / 15 \\
35 / 15\end{array}$ & Populational & 29.428 .8 & 29 & 22.923 .9 & $\begin{array}{l}\text { Age, gender, } \\
\text { BMI,number } \\
\text { of cigarettes/ } \\
\text { day, catchment } \\
\text { area }\end{array}$ & NA & $\begin{array}{l}\text { Serum, not high } \\
\text { sensitive immuno } \\
\text { assay }\end{array}$ & $\begin{array}{l}\mathrm{DM}(n=9) \text {. } \\
\text { Exclusions: other } \\
\text { relevant clinical } \\
\text { pathologies }\end{array}$ & \\
\hline $\begin{array}{l}\text { Fawzi } \\
\text { et al., } 2011\end{array}$ & 2011 & Egypt & \begin{tabular}{|l} 
Chronic \\
SZ \\
Control
\end{tabular} & $92 / 0200 / 0$ & $\begin{array}{l}\text { Outpatient } \\
\text { unit }\end{array}$ & 28.428 .8 & NA & $27 \quad 26.4$ & $\begin{array}{l}\text { Age, gender, } \\
\text { BMI, lifestile }\end{array}$ & $147 \quad 132$ & $\begin{array}{l}\text { Plasma, high sensitive } \\
\text { latex assay }\end{array}$ & $\begin{array}{l}\text { Exclusions: DM } \\
\text {, HAS, CVD, } \\
\text { infectionsand use of } \\
\text { anti-inflammatory } \\
\text { orimmunos- } \\
\text { supressants }\end{array}$ & $\begin{array}{l}\text { Drug-naïve } \\
\text { or free Drug- } \\
\text { naïve }\end{array}$ \\
\hline $\begin{array}{l}\text { Hope et al., } \\
2011\end{array}$ & 2011 & Norway & \begin{tabular}{|l|} 
Chronic \\
SZ \\
Control
\end{tabular} & \begin{tabular}{|l|}
$89 / 64$ \\
$105 / 134$
\end{tabular} & Populational & $36.2 \quad 36$ & & \begin{tabular}{|ll}
26 & 24.4
\end{tabular} & $\begin{array}{l}\text { Age, BMI, } \\
\text { catchment area }\end{array}$ & \begin{tabular}{|ll}
86 & NA \\
\end{tabular} & $\begin{array}{l}\text { Plasma, high sensitive } \\
\text { enzime immunoassay }\end{array}$ & $\begin{array}{l}\text { DM }(n=4) \text { and } \\
\text { CVD }(n=11) . \\
\text { Exclusions:other } \\
\text { relevant clinical } \\
\text { pathologies }\end{array}$ & \begin{tabular}{|l} 
Typical and \\
Atypical \\
antipsychotics
\end{tabular} \\
\hline $\begin{array}{l}\text { Suvisaari } \\
\text { et al., } 2011\end{array}$ & 2011 & Finland & \begin{tabular}{|l} 
Chronic \\
SZ \\
Control
\end{tabular} & $\begin{array}{l}39 / 63 \\
39 / 63\end{array}$ & Populational & 55.755 .78 & NA & 28.626 .4 & $\begin{array}{l}\text { Age, gender, } \\
\text { BMI }\end{array}$ & \begin{tabular}{|ll}
37 & 27
\end{tabular} & $\begin{array}{l}\text { Plasma, high sensitive } \\
\text { immunotur- } \\
\text { bidometric test }\end{array}$ & $\begin{array}{l}\text { DM }(n=11), \\
\text { Exclusions: other } \\
\text { relevant clinical } \\
\text { pathologies, } \\
\text { infections }\end{array}$ & \begin{tabular}{|l} 
Typical and \\
Atypical \\
antipsychotics
\end{tabular} \\
\hline $\begin{array}{l}\text { Hepgul } \\
\text { et al. } 2012\end{array}$ & 2012 & England & \begin{tabular}{|l|}
$\mathrm{SZ}$ in \\
FEP \\
Control
\end{tabular} & NA & $\begin{array}{l}\text { Inpatient and } \\
\text { outpatient } \\
\text { unit }\end{array}$ & 33.533 .1 & NA & 25.625 .1 & No & NA & $\begin{array}{l}\text { Serum, high sensitive } \\
\text { enzime immunoassay }\end{array}$ & $\begin{array}{l}\text { Exclusions: DM } \\
\text {, HAS, CVD, } \\
\text { infectionsand use of } \\
\text { anti-inflammatory or } \\
\text { immunossupressants }\end{array}$ & Drug-free \\
\hline $\begin{array}{l}\text { Dickerson } \\
\text { et al.,2013 }\end{array}$ & 2013 & $\begin{array}{l}\text { United } \\
\text { States }\end{array}$ & $\begin{array}{l}\text { Chronic } \\
\text { SZ } \\
\text { Control }\end{array}$ & \begin{tabular}{|l|}
$177 / 118$ \\
$84 / 144$
\end{tabular} & $\begin{array}{l}\text { Inpatient and } \\
\text { outpatient } \\
\text { unit }\end{array}$ & $39 \quad 32.2$ & 20.3 & 30.327 .8 & No & $183 \quad 36$ & $\begin{array}{l}\text { Serum, high sensitive } \\
\text { enzime immunoassay }\end{array}$ & $\begin{array}{l}\mathrm{DM}(n=17) . \\
\text { Exclusions: other } \\
\text { relevant clinical } \\
\text { pathologies }\end{array}$ & \begin{tabular}{|l} 
Typical and \\
Atypical \\
antipsychotics
\end{tabular} \\
\hline $\begin{array}{l}\text { Joshi et al., } \\
2013\end{array}$ & 2013 & India & \begin{tabular}{|l|} 
Chronic \\
SZ \\
Control
\end{tabular} & $\begin{array}{l}29 / 16 \\
21 / 20\end{array}$ & $\begin{array}{l}\text { Inpatient and } \\
\text { outpatient } \\
\text { unit }\end{array}$ & 38.535 .8 & 23.90 & 27.326 .5 & $\begin{array}{l}\text { Age, BMI, } \\
\text { catchment }\end{array}$ & NA & $\begin{array}{l}\text { Plasma, high sensitive } \\
\text { enzime immunoassay }\end{array}$ & $\begin{array}{l}\text { Exclusions: DM } \\
\text {, HAS, CVD, } \\
\text { infectionsand use of } \\
\text { anti-inflammatory or } \\
\text { immunossupressants }\end{array}$ & $\begin{array}{l}\text { Typical } \\
\text { antipsychotics }\end{array}$ \\
\hline $\begin{array}{l}\text { Kuo et al., } \\
2013\end{array}$ & 2013 & Taiwan & $\begin{array}{l}\text { Chronic } \\
\text { SZ } \\
\text { Control }\end{array}$ & $\begin{array}{l}19 / 14 \\
12 / 18\end{array}$ & $\begin{array}{l}\text { Outpatient } \\
\text { unit }\end{array}$ & 37.838 .8 & 33.90 & 29.528 .3 & Age, BMI & NA & $\begin{array}{l}\text { Plasma, high sensitive } \\
\text { latex assay }\end{array}$ & $\begin{array}{l}\text { Exclusions: DM } \\
\text {, HAS, CVD, } \\
\text { infections and use of } \\
\text { anti-inflammatory or } \\
\text { immunossupressants }\end{array}$ & \begin{tabular}{|l} 
Typical and \\
Atypical \\
antipsychotics
\end{tabular} \\
\hline $\begin{array}{l}\text { Lin et al., } \\
2013\end{array}$ & 2013 & Taiwan & $\begin{array}{l}\text { Chronic } \\
\text { SZ } \\
\text { Control }\end{array}$ & $\begin{array}{l}16 / 20 \\
16 / 20\end{array}$ & $\begin{array}{l}\text { Inpatient and } \\
\text { outpatient } \\
\text { unit }\end{array}$ & 35.737 .3 & 23.79 & 24.622 .9 & $\begin{array}{l}\text { Age, gender, } \\
\text { BMI, }\end{array}$ & NA & $\begin{array}{l}\text { Serum, high sensitive } \\
\text { immunonephrelometry } \\
\text { assay }\end{array}$ & \begin{tabular}{|l|} 
Exclusions: DM \\
, HAS, CVD, \\
infectionsand use of \\
anti-inflammatory or \\
immunossupressants
\end{tabular} & \begin{tabular}{|l} 
Atypical \\
antipsychotics
\end{tabular} \\
\hline $\begin{array}{l}\text { Vuksan- } \\
\text { Cusa et al., } \\
2013\end{array}$ & 2013 & Croatia & $\begin{array}{l}\text { Chronic } \\
\text { SZ } \\
\text { Control }\end{array}$ & NA & $\begin{array}{l}\text { Inpatient } \\
\text { unit }\end{array}$ & 26.924 .9 & 15.7 & 26.924 .9 & $\begin{array}{l}\text { Age, gender, } \\
\text { BMI, }\end{array}$ & NA & $\begin{array}{l}\text { Plasma, high sensitive } \\
\text { immunoturbidometric } \\
\text { test }\end{array}$ & \begin{tabular}{|l} 
Exclusions: DM \\
, HAS, CVD, \\
infectionsand use of \\
anti-inflammatory or \\
immunossupressants
\end{tabular} & $\begin{array}{l}\text { Atypical } \\
\text { antipsychotics }\end{array}$ \\
\hline $\begin{array}{l}\text { Berardis } \\
\text { et al., } 2014\end{array}$ & 2014 & Italy & \begin{tabular}{|l|} 
SZ in \\
FEP \\
Control
\end{tabular} & $\begin{array}{l}13 / 17 \\
13 / 17\end{array}$ & $\begin{array}{l}\text { Inpatient } \\
\text { unit }\end{array}$ & 25.925 .5 & 24.90 & 22.123 .5 & Age, gender & NA & $\begin{array}{l}\text { Plasma, high sensitive } \\
\text { immunonephrelometry } \\
\text { assay }\end{array}$ & \begin{tabular}{|l|} 
Exclusions: DM \\
, HAS, CVD, \\
infections and use of \\
anti-inflammatory or \\
immunossupressants
\end{tabular} & Drug-naïve \\
\hline $\begin{array}{l}\text { Frydecka } \\
\text { et al., } 2014\end{array}$ & 2014 & Poland & $\begin{array}{l}\text { Chronic } \\
\text { SZ } \\
\text { Control }\end{array}$ & $\begin{array}{l}69 / 82 \\
103 / 91\end{array}$ & $\begin{array}{l}\text { Inpatient and } \\
\text { outpatient } \\
\text { unit }\end{array}$ & 37.839 .2 & 25.20 & 27.1126 .9 & $\begin{array}{l}\text { Age, gender, } \\
\text { BMI }\end{array}$ & NA & $\begin{array}{l}\text { Serum, high sensitive } \\
\text { enzime immunoassay }\end{array}$ & \begin{tabular}{|l|} 
Exclusions: DM, \\
HAS, CVD, \\
infections and use of \\
anti-inflammatory or \\
immunossupressants
\end{tabular} & NA \\
\hline
\end{tabular}




\begin{tabular}{|c|c|c|c|c|c|c|c|c|c|c|c|c|c|}
\hline $\begin{array}{l}\text { Klemettila } \\
\text { et al., } 2014\end{array}$ & 2014 & Finland & $\begin{array}{l}\text { Chronic } \\
\text { SZ } \\
\text { Control }\end{array}$ & $\begin{array}{l}105 / 85 \\
403 / 500\end{array}$ & $\begin{array}{l}\text { Inpatient and } \\
\text { outpatient } \\
\text { unit }\end{array}$ & $42.9 \quad 46$ & NA & 29.9226 .5 & No & $101 \mathrm{NA}$ & $\begin{array}{l}\text { Plasma, high sensitive } \\
\text { enzime immunoassay }\end{array}$ & $\begin{array}{l}\text { Exclusions: DM, } \\
\text { HAS, CVD, } \\
\text { infectionsand use of } \\
\text { anti-inflammatory or } \\
\text { immunossupressants }\end{array}$ & Clozapine \\
\hline $\begin{array}{l}\text { Stojanovic } \\
\text { et al., } 2014\end{array}$ & 2014 & Spain & $\begin{array}{l}\text { SZ in } \\
\text { FEP } \\
\text { Control }\end{array}$ & $\begin{array}{l}48 / 29 \\
12 / 13\end{array}$ & $\begin{array}{l}\text { Outpatient } \\
\text { unit }\end{array}$ & 24.327 .3 & NA & 24.421 .6 & No & 53 & $\begin{array}{l}\text { Plasma, high sensitive } \\
\text { immunoturbidometric } \\
\text { test }\end{array}$ & NA & $\begin{array}{l}\text { Typical and } \\
\text { Atypical } \\
\text { antipsychotics }\end{array}$ \\
\hline $\begin{array}{l}\text { Inoshita } \\
\text { et al., } 2016\end{array}$ & 2016 & Japan & $\begin{array}{l}\text { Chronic } \\
\text { SZ } \\
\text { Control }\end{array}$ & $\begin{array}{l}241 / 177 \\
422 / 943\end{array}$ & Populational & $62.5 \quad 62.6$ & NA & NA & Age, gender & NA & $\begin{array}{l}\text { Serum, high sensitive } \\
\text { enzime immunoassay }\end{array}$ & $\begin{array}{l}\text { Exclusions: CRP } \\
\text { concentration either } \\
\text { below } 0.02 \mathrm{mg} / \mathrm{dl} \text { or } \\
\text { above } 10 \mathrm{mg} / \mathrm{dl}\end{array}$ & $\begin{array}{l}\text { Typical and } \\
\text { Atypical } \\
\text { antipsychotics }\end{array}$ \\
\hline
\end{tabular}

Abbreviations: BMI, body-mass index; CRP, C-reactive protein; CVD, cardiovascular diseases; DM, Diabetes Mellitus; HAS, hypertension; HDRS, Hamilton Depression Rating Scale; NA, not available; YMRS, Young Mania rating Scale.

moderately increased in people with SZ (standardized mean difference (SMD) $0.53,95 \%$ CI 0.30 to 0.76 ), with significant heterogeneity among studies $\left(\mathrm{I}^{2}=92.5 \%\right.$, $P<0.001$ ) (Figure 2). We then conducted subgroup analyses stratified by study region, sample size, clinical setting, mean age, age of SZ onset, body mass index, adjusted controls and high-sensitivity CRP assay used or not. The findings did not largely alter compared with that of the main analysis for most of the subgroups (Table 2). A bordine estimates were seen for studies for clinical setting of inpatient unit (SMD 0.66, 95\% CI-0.05 to 1.38) and outpatient unit (SMD 0.82, 95\% CI-0.05 to 1.38 ).

\section{Study region}

Subgroup analysis stratified by study region showed that serum and plasma CRP levels were increased moderately in studies conducted in European countries ( $n=11$, pooled SMD $0.42,95 \%$ CI 0.12 to 0.72 ) and significantly in Asian/African countries $(n=6$, pooled
SMD $0.73,95 \%$ CI 0.26 to 1.21 ). We found statistically significant difference for inter-study heterogeneity $(P<0.001)$.

\section{Clinical setting}

Meta-analysis stratified by clinical setting demonstated that serum and plasma CRP levels were increased moderately in studies performed in combination with inpatient and outpatient unit $(n=8$, pooled SMD $0.50,95 \%$ CI 0.24 to 0.76 ) and slightly in populationbased samples $(n=4$, pooled SMD $0.31,95 \%$ CI 0.17 to 0.80$)$. We found statistically significant difference for inter-study heterogeneity $(P<0.001)$.

\section{Sample size}

Subgroup analysis stratified by sample size indicated that serum and plasma CRP levels were increased moderately in studies with large sample size $(\geq 100)$

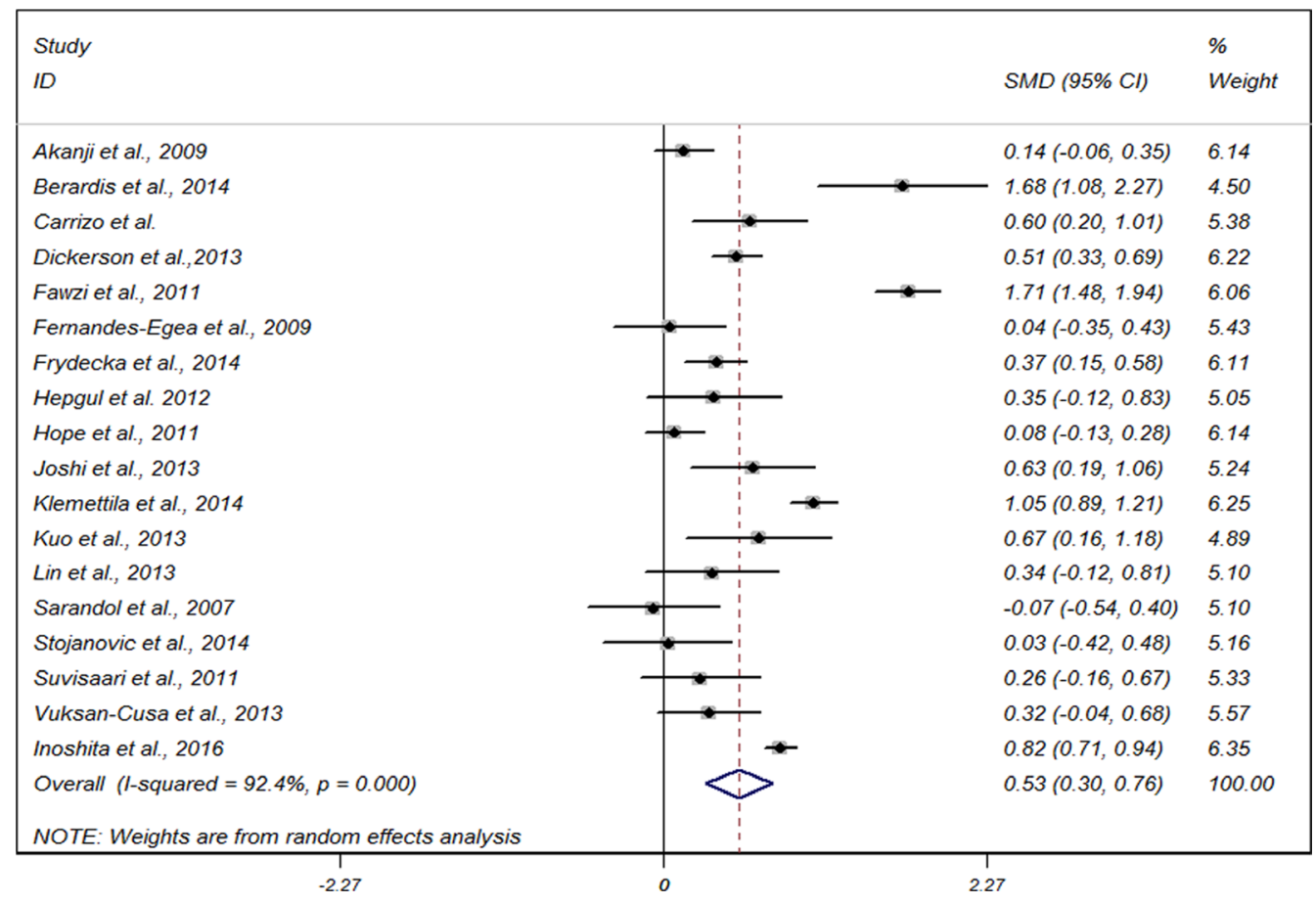

Figure 2: Forest plot for meta-analysis of the association between C-reactive protein and risk of schizophrenia with the use of a random-effects model. SMD, standardized mean difference; CI, confidence interval. 
Table 2: Main results of subgroup analyses to explore sources of heterogeneity based on some investigated variables for association between $\mathrm{C}$-reactive protein levels and risk of schizophrenia

\begin{tabular}{|c|c|c|c|}
\hline Variables & $\begin{array}{l}\text { Heterogeneity } \\
\left(\mathbf{I}^{2} \% ; P_{\text {het }}\right)\end{array}$ & SMD 95\% CI & $\boldsymbol{P}_{\text {interaction }}$ \\
\hline Total & $18(92.5 ;<0.001)$ & $0.53(0.30$ to 0.76$)$ & NA \\
\hline Study region & & & $<0.001$ \\
\hline USA & $1(-,-)$ & $0.51(0.33$ to 0.69$)$ & \\
\hline Europe & $11(89.6,<0.001)$ & $0.42(0.12$ to 0.72$)$ & \\
\hline Asia/Africa & $6(95.3,<0.001)$ & $0.73(0.26$ to 1.21$)$ & \\
\hline Sample size & & & 0.075 \\
\hline$\geq 100$ & $10(95.5,<0.001)$ & $0.52(0.21$ to 0.83$)$ & \\
\hline$<100$ & $6(77.7,<0.001)$ & $0.63(0.22$ to 1.03$)$ & \\
\hline Clinical setting & & & $<0.001$ \\
\hline Inpatient unit & $3(91.6 \%,<0.001)$ & $0.66(-0.05$ to 1.38$)$ & \\
\hline Outpatient unit & $3(92.5 \%,<0.001)$ & $0.82(-0.28$ to 1.93$)$ & \\
\hline Both units & $8(84.3,<0.001)$ & $0.50(0.24$ to 0.76$)$ & \\
\hline Population-based & $4(95.9,<0.001)$ & $0.31(0.17$ to 0.80$)$ & \\
\hline Mean age & & & $<0.001$ \\
\hline$<30$ years & $5(95.9,<0.001)$ & $0.76(0.07$ to 1.58$)$ & \\
\hline $30-50$ years & $11(87.7,<0.001)$ & 0.43 (0.19 to 0.67$)$ & \\
\hline$\geq 50$ years & $2(84,6,<0.001)$ & $0.58(0.03$ to 1.12$)$ & \\
\hline Age of onset & & & $<0.001$ \\
\hline$\leq 30$ years & $7(74.6,0.001)$ & $0.50(0.25$ to 0.75$)$ & \\
\hline$>30$ years & $2(0,0.591)$ & $0.81(0.70$ to 0.93$)$ & \\
\hline Body mass index & & & $<0.001$ \\
\hline$\leq 25 \mathrm{~kg} / \mathrm{m}^{2}$ & $5(85.1,<0.001)$ & $0.38(0.16$ to 0.92$)$ & \\
\hline $25-30 \mathrm{~kg} / \mathrm{m}^{2}$ & $11(93.5,<0.001)$ & $0.60(0.29$ to 0.92$)$ & \\
\hline Adjusted controls & & & 0.077 \\
\hline Yes & $13(93.7,<0.001)$ & $0.53(0.23$ to 0.84$)$ & \\
\hline No & $5(87.8,<0.001)$ & $0.54(0.19$ to 0.90$)$ & \\
\hline High-sensitivity CRP assay & & & 0.003 \\
\hline Yes & $17(92.6,<0.001)$ & $0.56(0.33$ to 0.80$)$ & \\
\hline No & $1(-,-)$ & $0.04(-0.35$ to 0.43$)$ & \\
\hline
\end{tabular}

Abbreviations: CI, confidence interval; CRP, C-reactive protein; het, heterogeneity; NA, not available; SMD, standardized mean difference.

$(n=10$, pooled SMD $0.52,95 \%$ CI 0.21 to 0.83$)$; similar results were also obtained for studies with small sample size $(<100)(n=6$, pooled SMD $0.63,95 \%$ CI $(0.22$ to 1.03).We found no statistically significant difference for inter-study heterogeneity $(P=0.075)$.

Age

Subgroup analysis stratified by age indicated that serum and plasma CRP levels were increased significantly in studies with participants'age $<30$ years $(n=5$, pooled SMD $0.76,95 \%$ CI 0.07 to 1.58 ); but moderately in studies with participants'age ranging from 30 to 50 years $(n=11$, pooled SMD $0.43,95 \%$ CI 0.19 to 0.67 ); similar results were also obtained for studies with participants'age $\geq 50$ years ( $n=2$, pooled SMD $0.58,95 \%$ CI 0.03 to 1.12 ). We found statistically significant difference for inter-study heterogeneity $(P<0.001)$.

\section{Age of SZ onset}

Subgroup analysis stratified by age of SZ onset showed that serum and plasma CRP levels were increased moderately in studies with participants' age of SZ onset $\leq 30$ years $(n=7$, pooled SMD $0.50,95 \%$ CI 0.25 to 0.75$)$; but significantly in studies with participants'age ranging from 30 to 50 years $(n=11$, pooled SMD 0.43, 95\% CI 0.19 to 0.67 ); similar results were also obtained for 
studies with participants' age of SZ onset $>30$ years ( $n=2$, pooled SMD $0.81,95 \%$ CI 0.70 to 0.93 ). We found statistically significant difference for inter-study heterogeneity $(P<0.001)$.

\section{Adjusted variables for controls}

Subgroup analysis stratified by adjusted variables for controls showed that serum and plasma CRP levels were increased moderately in studies with $(n=13$, pooled SMD $0.53,95 \%$ CI 0.23 to 0.84 ) and without adjusted variables for controls $(n=5$, pooled SMD 0.54 , $95 \%$ CI 0.19 to 0.90$)$. We found no statistically significant difference for inter-study heterogeneity $(P<0.077)$.

\section{Sensitivity analysis and publication bias}

Sensitivity analysis showed that serum and plasma CRP levels were increased moderately in studies involved only high-sensitivity CRP assay ( $n=17$, pooled SMD $0.56,95 \%$ CI 0.33 to 0.80 ). No significant funnel plot asymmetry was detected as was shown in Figure 3, indicating no publication bias, which was further confirmed by Begg's rank correlation test $(P=0.544)$ and Egger's regression test $(P=0.292)$. Duval and Tweedie's trim and fill method indicated that no missing study was inputed and the adjusted SMD was the same as the primary one, confirming the robustness of the analysis.

\section{DISCUSSION}

In this meta-analysis based on 18 case-control studies, we found that serum and plasma CRP levels were moderately increased in patients with SZ, irrespective of study region, sample size of included studies, patient mean age, age of SZ onset and patient body mass index. We noticed that patients in Asia or Africa and whose age less than 30 years were more substantially increase in CRP levels.

The potential biological mechanism for the associations between some inflammatary factors and SZ has not been fully understood. Hsuchou et al. found that high peripheral levels of CRP could increase the permeability of the blood-brain barrier through the adjustment of the function of tight junctions, which contributed to the increase in some pro-inflammatory cytokines, such as CRP to enter the central nervous system [29].

The high levels of CRP in central nervous system has been reported to play an important part in some psychiatric dysfunctions, such as SZ [30, 31]. Experimental study showed that CRP affected viability of microglia and astrocytes, accelerating cell gliosis [32], thus leading to the release of some pro-inflammatroy factors, such as IL-6 and transforming growth factor- $\beta$. In addition, reports also showed that elevated CRP levels could influence the microcirculatory system in the blood-brain barrier, thus affecting neurotransmitter synthesis and neurotransmission [33-38]. Moreover, elevated CRP levels were reported to be associated with the severity of clinical symptoms, cognitive and sensory impairments in SZ [39-42]. The rationale that plasma CRP levels were increased significantly in studies with participants'age less than 30 years probably lies in that in the early stages of SZ, a particularly large number of inflammatory substances will be secreted, such as blood CRP and interleukin-10, which are very likely to be related to the development of SZ [57].

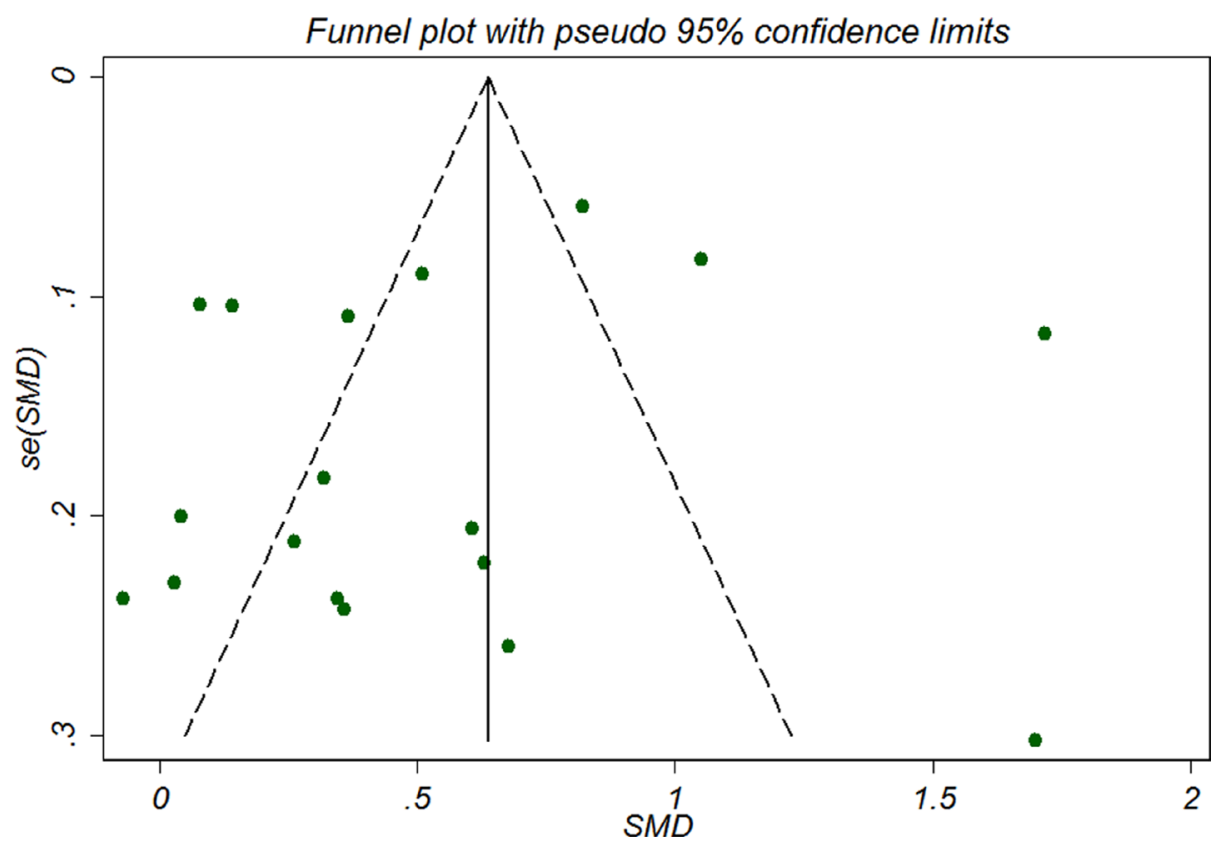

Figure 3: Funnel plot of publication bias in the selection of studies for assessing the relationship between C-reactive protein and risk of schizophrenia. SMD, standardized mean difference. 


\section{Strength of the study}

This updated literature search identified two systematic review and meta-analyses on the same topic $[14,43]$, but both of them focused on studies with mixed study design. Though solely one newly published study has been added to this analysis [10], this is a quite large sample size case-control study (418 cases/1365 controls) with greater statistical power. The findings of our studies are consistent with those two meta-analyses from mixed cross-sectional studies and case-control studies (60). Miller et al. [43] found that CRP levels were slightly to moderately increased in people with SZ (SMD 0.45, 95\% CI 0.34 to 0.55 ) by pooling 8 cross-sectional studies, and Fernandes et al. [14] concluded that CRP levels were moderately to significantly increased in persons with SZ (SMD $0.66,95 \%$ CI 0.43 to 0.88 ). Strength of our metaanalysis lies in the following three aspects. Firstly, most of the included studies in the previous meta-analyses were cross-sectional in study design. An known limitation of a cross-sectional study is that exposure and outcome are generally evaluated simutaneously and we therefore cannot draw conclusions on the casual-relationship between exposure and outcome. Hence, the underlying hypothesis obtained from the previous meta-analyses is that the prevalance of SZ is an immediate outcome following exposure of elevated CRP levels. The investigation of the real effects caused by continuous long-term exposure may require a different study design, such as our case-control study or cohort study [44]. Secondly, heterogeneity was noted among the included studies but we tried to account for this variation by conducting sensitivity analysis. The asymmetry of funnel plot indicated the overestimation of the effect size due to the lack of negative studies with small sample size. However, Begg's rank correlation test and Egger's regression test suggested little evidence of publication bias. Moreover, when applying the trim and fill method, no additional hypothised negative studies with small sample size were inputed, suggesting the robustness of the meta-analysis. Thirdly, it is the first study to suggest that younger patients with SZ whose age less than 30 years were more substantially increase in CRP levels. Though this potential reason is unclear, it has been suggested to be related with a greater reactivity of the immune system in younger patients [45]. However, further large well designed studies are warrented to validate this association.

Some inherent limitations do exist in our study. We report an increase in serum and plasma CRP levels in patients with SZ by pooling the eligible studies over the last decade. In our meta-analysis, we found the pooled SMD was 0.53 (95\% CI 0.30 to 0.76$)$ for the association between serum and plasma CRP levels and risk of SZ from the 18 studies included. The study quality of evidence obtained from NOS score was moderate and derived from case-control studies. However, still some other confounders remained due to factors that could not be accounted for such as physical activity, waist circumference, smoking habit, vitamin D intake, and subclinical infections. Most studies included in our analysis did not provide such data, which could explain the heterogeneity noted in the pooled analysis. Although subgroup analyses have been performed for some of the existing confounders, the investigated factors could only explain some of the heterogeneity. Moreover, many of the other analyses, such as dose-response relationship could not be conducted due to the lack of detailed information from original reports. Furthermore, the possible sources of heterogeneity was explored through subgroup analyses and sensitivity analyses. However, the results of these two methods did not allow us to attribute heterogeneity to any single study as the sole source of the high heterogeneity we obtained in most analyses. Secondly, this updated meta-analysis on serum and plasma CRP levels in patients with SZ compared with non-SZ controls provided us with summary estimates originating from one type of observational study (case-control study). Therefore, no definite causal conclusion can be drawn from this metaanalysis. High serum and plasma CRP level is only one of the inflammation-related factors known to be associated with the risk of SZ. Other factors such as smoking habit and subclinical infections could also be additional related factors. Thirdly, like any meta-analysis, this one is also dependent on the quality of the included studies, and our findings need to be further confirmed by studies specifically designed to demonstrate the unclear points we raised. Finally, the restriction of our meta-analysis to English language studies may have led to language bias with potentially relevant studies published in other languages being missed.

In summary, our meta-analyses provide evidence that higher CRP levels are associated with increased risk of SZ, especially for young adult patients less than 30 years. Future studies should be focused on whether changes in CRP levels have a causal relationship with the development of SZ.

\section{MATERIALS AND METHODS}

\section{Literature search and study selection}

The Preferred reporting items for systematic reviews and meta-analyses (PRISMA) statement was used when we performed this systematic literature review [46]. We systematically searched databases of Pubmed, EMBASE and the Cochrane Library from inception till November 1, 2016 for relevant studies, using the predefined search strategies (Supplementary search strategy 1-3). The following MeSH terms combined with free text words were used:schizophrenia /schizophreni* /schizoid / psychosis /schizophreniform/schizoaffective/psychotic disorders and C-reactive protein /CRP/hsCRP/hs-CRP. Additional related journal articles were identified by 
manual scanning of reference lists of articles, and the journals selected were JAMA Psychiatry, American Journal of Psychiatry, Molecular Psychiatry, British Journal of Psychiatry and European Psychiatry. We only included studies in English peer-review journals.

Studies were considered eligible in the metaanalysis according to the following criteria: 1) adult patients diagnosed with SZ based on Diagnostic and Statistical Manual for Mental Disorder-Fourth EditionText Revised (DSM-IV-TR) were enrolled in the study; 2) case-control studies with the non-SZ comparisons measuring serum or plasma CRP levels. We excluded studies with duplicate data or studies that reported CRP levels using dichotomous data (ie, positive or negative), or studies without a control group. In addition, we did not include unpublished literature due to the insufficient data obtained from these studies.

\section{Data extraction and bias assessment}

Two authors (Z.W. and P.L.) independently searched, identified the related studies, extracted data and evaluated the study quality. When discrepancies occured, a third author (G.C.) made the definitive decision for study eligibility and data extraction. We extracted the following data including first author, publication year , research country, study subjects, clinical setting, sex, age and BMI of the study subjects, age of SZ onset, adjusted variables for controls, percent of the current smokers, CRP assay type, comorbidities and psychiatric drugs used. If necessary, we consulted the original data from the authors of the studies to collect missing information. The Newcastle-Ottawa Scales (NOS) was used to assess quality of the included studies [47], which applied three domains for assessment and allocated a total score of nine points. Quality categories were determined by the NOS score of each study. We defined that the score of high quality with 7 or more, medium quality from 4 to 6 and low quality less than 4 .

\section{Statistical analysis}

For continuous outcomes reported on different measurement methods for CRP levels, we applied standardised mean difference (SMD) estimates of the differences in CRP levels between patients with SZ and non-SZ controls as the effect size. The value of SMD being 0.2 was set to indicate a slight effect, meaning a small difference in CRP levels between patients with SZ and non-SZ controls, 0.5 a moderate effect, and 0.8 a significant effect [48]. The heterogeneity among the included studies was investigated using $\mathrm{I}^{2}$ and $Q$ test statistics, with an $\mathrm{I}^{2}$ more than $50 \%$ or a $P$ value less than 0.1 from Cochran's Q-test indicating significant heterogeneity [49]. Summary estimates in the present meta-analysis were pooled using a random-effects model due to the predictable significant inter-study difference in the enrolled population, study design, or the treatment strategy [50]. We used funnel plots to visually inspect publication bias, along with Begg's rank correlation test [51] and Egger's regression test [52]. We also estimated the number of potential missing studies from a metaanalysis using the trim and fill method [53]. Some planned subgroup analyses were performed to explore possible causes of heterogeneity and between-subgroup interactions were calculated using the chi-squared significance test [54]. All meta-analyses were conducted using the software STATA version 12.0 (StataCorp LP, College Station, TX).

\section{CONFLICTS OF INTEREST}

None.

\section{GRANT SUPPORT}

This work was supported by the Natural Science Foundation of Heilongjiang, China (H201497).

\section{REFERENCES}

1. Potvin S, Stip E, Sepehry AA, Gendron A, Bah R, Kouassi E. Inflammatory cytokine alterations in schizophrenia: a systematic quantitative review. Biological psychiatry. 2008; 63:801-808.

2. Brown AS, Derkits EJ. Prenatal infection and schizophrenia: a review of epidemiologic and translational studies. The American journal of psychiatry. 2010; 167:261-280.

3. Brown AS. The environment and susceptibility to schizophrenia. Progress in neurobiology. 2011; 93:23-58.

4. Miller BJ, Buckley P, Seabolt W, Mellor A, Kirkpatrick B. Meta-analysis of cytokine alterations in schizophrenia: clinical status and antipsychotic effects. Biological psychiatry. 2011; 70:663-671.

5. Richard MD, Brahm NC. Schizophrenia and the immune system: pathophysiology, prevention, and treatment. American journal of health-system pharmacy. 2012; 69:757-766.

6. Canetta S, Sourander A, Surcel HM, Hinkka-YliSalomaki S, Leiviska J, Kellendonk C, McKeague IW, Brown AS. Elevated maternal C-reactive protein and increased risk of schizophrenia in a national birth cohort. The American journal of psychiatry. 2014; 171:960-968.

7. Canetta SE, Bao Y, Co MD, Ennis FA, Cruz J, Terajima M, Shen L, Kellendonk C, Schaefer CA, Brown AS. Serological documentation of maternal influenza exposure and bipolar disorder in adult offspring. The American journal of psychiatry. 2014; 171:557-563.

8. Dantzer R, O'Connor JC, Freund GG, Johnson RW, Kelley KW. From inflammation to sickness and depression: when the immune system subjugates the brain. Nature reviews Neuroscience. 2008; 9:46-56. 
9. Wium-Andersen MK, Orsted DD, Nordestgaard BG. Elevated C-reactive protein and late-onset bipolar disorder in 78809 individuals from the general population. The British journal of psychiatry. 2016; 208:138-145.

10. Inoshita M, Numata S, Tajima A, Kinoshita M, Umehara H, Nakataki M, Ikeda M, Maruyama S, Yamamori H, Kanazawa T, Shimodera S, Hashimoto R, Imoto I, et al. A significant causal association between $\mathrm{C}$-reactive protein levels and schizophrenia. Scientific reports. 2016; 6:26105.

11. Sarandol A, Kirli S, Akkaya C, Ocak N, Eroz E, Sarandol E. Coronary artery disease risk factors in patients with schizophrenia: effects of short term antipsychotic treatment. Journal of psychopharmacology (Oxford, England). 2007; 21:857-863.

12. Hope S, Dieset I, Agartz I, Steen NE, Ueland T, Melle I, Aukrust P, Andreassen OA. Affective symptoms are associated with markers of inflammation and immune activation in bipolar disorders but not in schizophrenia. Journal of psychiatric research. 2011; 45:1608-1616.

13. Fernandez-Egea E, Bernardo M, Donner T, Conget I, Parellada E, Justicia A, Esmatjes E, Garcia-Rizo C, Kirkpatrick B. Metabolic profile of antipsychotic-naive individuals with non-affective psychosis. The British journal of psychiatry. 2009; 194:434-438.

14. Fernandes BS, Steiner J, Bernstein HG, Dodd S, Pasco JA, Dean OM, Nardin P, Goncalves CA, Berk M. C-reactive protein is increased in schizophrenia but is not altered by antipsychotics: meta-analysis and implications. Molecular psychiatry. 2016; 21:554-564.

15. Vuksan-Cusa B, Sagud M, Jakovljevic M, Peles AM, Jaksic N, Mihaljevic S, Zivkovic M, Mikulic SK, Jevtovic S. Association between C-reactive protein and homocysteine with the subcomponents of metabolic syndrome in stable patients with bipolar disorder and schizophrenia. Nordic journal of psychiatry. 2013; 67:320-325.

16. Suvisaari J, Loo BM, Saarni SE, Haukka J, Perala J, Saarni SI, Viertio S, Partti K, Lonnqvist J, Jula A. Inflammation in psychotic disorders: a population-based study. Psychiatry research. 2011; 189:305-311.

17. Stojanovic A, Martorell L, Montalvo I, Ortega L, Monseny R, Vilella E, Labad J. Increased serum interleukin-6 levels in early stages of psychosis: associations with at-risk mental states and the severity of psychotic symptoms. Psychoneuroendocrinology. 2014; 41:23-32.

18. Lin CC, Chang CM, Liu CY, Huang TL. Increased high-sensitivity C-reactive protein levels in Taiwanese schizophrenic patients. Asia-Pacific psychiatry. 2013; 5:E58-63.

19. Kuo FC, Lee CH, Hsieh CH, Kuo P, Chen YC, Hung YJ. Lifestyle modification and behavior therapy effectively reduce body weight and increase serum level of brainderived neurotrophic factor in obese non-diabetic patients with schizophrenia. Psychiatry research. 2013; 209:150-154.
20. Klemettila JP, Kampman O, Seppala N, Viikki M, Hamalainen M, Moilanen E, Leinonen E. Cytokine and adipokine alterations in patients with schizophrenia treated with clozapine. Psychiatry research. 2014; 218:277-283.

21. Joshi KB, Nillawar A, Thorat AP. Cardiovascular disease risk in schizophrenia patients: a case control study. Journal of clinical and diagnostic research. 2013; 7:2694-2696.

22. Hepgul N, Pariante CM, Dipasquale S, DiForti M, Taylor H, Marques TR, Morgan C, Dazzan P, Murray RM, Mondelli V. Childhood maltreatment is associated with increased body mass index and increased C-reactive protein levels in firstepisode psychosis patients. Psychological medicine. 2012; 42:1893-1901.

23. Frydecka D, Misiak B, Pawlak-Adamska E, Karabon L, Tomkiewicz A, Sedlaczek P, Kiejna A, Beszlej JA. Interleukin-6: the missing element of the neurocognitive deterioration in schizophrenia? The focus on genetic underpinnings, cognitive impairment and clinical manifestation. European archives of psychiatry and clinical neuroscience. 2015; 265:449-459.

24. Fawzi MH, Fawzi MM, Fawzi MM, Said NS. C-reactive protein serum level in drug-free male Egyptian patients with schizophrenia. Psychiatry research. 2011; 190:91-97.

25. Dickerson F, Stallings C, Origoni A, Vaughan C, Khushalani S, Yang S, Yolken R. C-reactive protein is elevated in schizophrenia. Schizophrenia research. 2013; 143:198-202.

26. De Berardis D, Conti CM, Marini S, Serroni N, Moschetta FS, Carano A, Valchera A, Iasevoli F, Fornaro M, Perna G, Di Iorio G, Martinotti G, Niolu C, et al. C-reactive protein level and its relationship with suicide risk and alexithymia among newly diagnosed, drug-naïve patients with non-affective psychosis. European Journal of Inflammation. 2013; 11:215-221.

27. Carrizo E, Fernandez V, Quintero J, Connell L, Rodriguez Z, Mosquera M, Acosta A, Baptista T. Coagulation and inflammation markers during atypical or typical antipsychotic treatment in schizophrenia patients and drug-free first-degree relatives. Schizophrenia research. 2008; 103:83-93.

28. Akanji AO, Ohaeri JU, Al-Shammri S, Fatania HR. Association of blood levels of C-reactive protein with clinical phenotypes in Arab schizophrenic patients. Psychiatry research. 2009; 169:56-61.

29. Hsuchou H, Kastin AJ, Mishra PK, Pan W. C-reactive protein increases $\mathrm{BBB}$ permeability: implications for obesity and neuroinflammation. Cellular physiology and biochemistry. 2012; 30:1109-1119.

30. Najjar S, Pearlman DM, Devinsky O, Najjar A, Zagzag D. Neurovascular unit dysfunction with blood-brain barrier hyperpermeability contributes to major depressive disorder: a review of clinical and experimental evidence. Journal of neuroinflammation. 2013; 10:142. 
31. Uranova NA, Zimina IS, Vikhreva OV, Krukov NO, Rachmanova VI, Orlovskaya DD. Ultrastructural damage of capillaries in the neocortex in schizophrenia. The world journal of biological psychiatry. 2010; 11:567-578.

32. Hsuchou H, Kastin AJ, Pan W. Blood-borne metabolic factors in obesity exacerbate injury-induced gliosis. Journal of molecular neuroscience. 2012; 47:267-277.

33. van der Mast RC. Pathophysiology of delirium. J Geriatr Psychiatry Neurol. 1998; 11:138-145; discussion 157-138.

34. Singh B, Chaudhuri TK. Role of C-reactive protein in schizophrenia: an overview. Psychiatry research. 2014; 216:277-285.

35. Kuhlmann CR, Librizzi L, Closhen D, Pflanzner T, Lessmann V, Pietrzik CU, de Curtis M, Luhmann HJ. Mechanisms of C-reactive protein-induced blood-brain barrier disruption. Stroke. 2009; 40:1458-1466.

36. Irani S, Lang B. Autoantibody-mediated disorders of the central nervous system. Autoimmunity. 2008; 41:55-65.

37. Hanson DR, Gottesman, II. Theories of schizophrenia: a genetic-inflammatory-vascular synthesis. BMC medical genetics. 2005; 6:7.

38. Breslow MJ, Miller CF, Parker SD, Walman AT, Traystman RJ. Effect of vasopressors on organ blood flow during endotoxin shock in pigs. The American journal of physiology. 1987; 252:H291-300.

39. Micoulaud-Franchi JA, Faugere M, Boyer L, Fond G, Richieri R, Faget C, Cermolacce M, Philip P, Vion-Dury J, Lancon C. Elevated C-reactive protein is associated with sensory gating deficit in schizophrenia. Schizophrenia research. 2015; 165:94-96.

40. Fan X, Pristach C, Liu EY, Freudenreich O, Henderson DC, Goff DC. Elevated serum levels of C-reactive protein are associated with more severe psychopathology in a subgroup of patients with schizophrenia. Psychiatry research. 2007; 149:267-271.

41. Dickerson F, Stallings C, Origoni A, Vaughan C, Khushalani S, Yolken R. Additive effects of elevated C-reactive protein and exposure to Herpes Simplex Virus type 1 on cognitive impairment in individuals with schizophrenia. Schizophrenia research. 2012; 134:83-88.

42. Barzilay R, Lobel T, Krivoy A, Shlosberg D, Weizman A, Katz N. Elevated C-reactive protein levels in schizophrenia inpatients is associated with aggressive behavior. European psychiatry. 2016; 31:8-12.

43. Miller BJ, Culpepper N, Rapaport MH. C-reactive protein levels in schizophrenia: a review and meta-analysis. Clinical schizophrenia \& related psychoses. 2014; 7:223-230.

44. Lahkola A, Tokola K, Auvinen A. Meta-analysis of mobile phone use and intracranial tumors. Scandinavian journal of work, environment \& health. 2006; 32:171-177.
45. Akiyama K. Serum levels of soluble IL-2 receptor alpha, IL-6 and IL-1 receptor antagonist in schizophrenia before and during neuroleptic administration. Schizophrenia research. 1999; 37:97-106.

46. Liberati A, Altman DG, Tetzlaff J, Mulrow C, Gotzsche PC, Ioannidis JP, Clarke M, Devereaux PJ, Kleijnen J, Moher D. The PRISMA statement for reporting systematic reviews and meta-analyses of studies that evaluate health care interventions: explanation and elaboration. Journal of clinical epidemiology. 2009; 62:e1-34.

47. Stang A. Critical evaluation of the Newcastle-Ottawa scale for the assessment of the quality of nonrandomized studies in meta-analyses. Eur J Epidemiol. 2010; 25:603-605.

48. Higgins JP, Green S. Cochrane handbook for systematic reviews of interventions: John Wiley \& Sons; 2011.

49. Hedges LV, Pigott TD. The power of statistical tests in meta-analysis. Psychological methods. 2001; 6:203-217.

50. DerSimonian R, Laird N. Meta-analysis in clinical trials. Controlled clinical trials. 1986; 7:177-188.

51. Begg CB, Mazumdar M. Operating characteristics of a rank correlation test for publication bias. Biometrics. 1994; 50:1088-1101.

52. Egger M, Davey Smith G, Schneider M, Minder C. Bias in meta-analysis detected by a simple, graphical test. Bmj. 1997; 315:629-634.

53. Duval S, Tweedie R. Trim and fill: A simple funnel-plotbased method of testing and adjusting for publication bias in meta-analysis. Biometrics. 2000; 56:455-463.

54. Altman DG, Bland JM. Interaction revisited: the difference between two estimates. Bmj. 2003; 326:219.

55. Metcalf SA, Jones PB, Nordstrom T, Timonen M, Mäki P, Miettunen J, Jääskeläinen E, Järvelin MR, Stochl J, Murray GK, Veijola J, Khandaker GM. Serum C-reactive protein in adolescence and risk of schizophrenia in adulthood: A prospective birth cohort study. Brain, Behavior, and Immunity. 2017; 59:53-259.

56. Zhang Q, Hong W, Li H, Peng F, Wang F, Li N, Xiang H, Zhang Z, Su Y, Huang Y, Zhang S, Zhao G, Zhou R, et al. Increased ratio of high sensitivity $\mathrm{C}$-reactive protein to interleukin-10 as a potential peripheral biomarker of schizophrenia and aggression. International journal of psychophysiology. 2017; 114:9-15.

57. Goto M, Sugimoto K, Hayashi S, Ogino T, Sugimoto M, Furuichi Y, Matsuura M, Ishikawa Y, Iwaki-Egawa S, Watanabe Y. Aging-associated inflammation in healthy Japanese individuals and patients with Werner syndrome. Experimental gerontology. 2012; 47:936-9. 